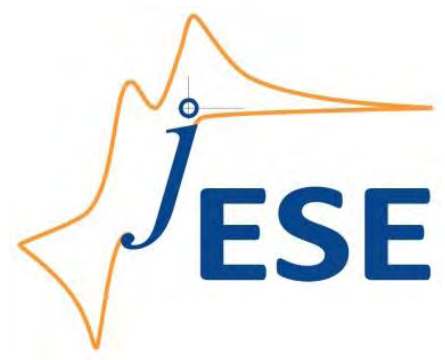

Open Access: ISSN 1847-9286

Original scientific paper

www.jESE-online.org

\title{
Effect of corrosion on flexural bond strength
}

Akshatha Shetty ${ }^{\bowtie}$, Katta Venkataramana and K. S. Babu Narayan

Department of Civil Engineering, NITK Surathkal-575025, India

${ }^{\triangle}$ Corresponding author: E-mail: akshathashetty16@gmail.com

Received: October 17, 2014; Revised: April 3, 2014; Published: September 22, 2014

\begin{abstract}
Corrosion is one of the main causes affecting durability of structures. Corrosion effects on structures cannot be ignored and replaced. To understand the performance of structures there is a need to study the rate at which different corrosion levels occur. Hence the present investigation has been taken up to study the behaviour of NBS (National Bureau of Standard) beam specimens made up of Ordinary Portland Cement (OPC) and Portland Pozzolona Cement (PPC) concrete matrix were subjected to accelerated corrosion for different corrosion levels of $2.5 \%$ to $10 \%$ at $2.5 \%$ interval. Results are compared with those for control beam specimen. It is observed that bond stress value decreases with the increase in corrosion levels. Also corrosion leads to the decline of load carrying capacity.
\end{abstract}

\section{Keywords}

OPC concrete; PPC concrete; Corrosion level; NBS beam; Strain; Corrosion current density

\section{Introduction}

Reinforcement corrosion has been identified as being the predominant deterioration mechanism for reinforced concrete structures, which seriously affects the serviceability and safety of structures.

Chloride ions from the external environment diffuse through concrete to the steel surface, leading to the depassivation of the protective layer and ultimately to the initiation of reinforcement corrosion. Corrosion consumes iron of the reinforcing bar progressively thereby reducing the cross sectional area. Corrosion increases its volume 2 to 6 times than that of the original steel; it causes volume expansion developing tensile stresses in concrete [1].

The corrosion of rebar in concrete is generally considered as an electrochemical process [2]. With attention of researchers focusing towards the prediction of the residual life of reinforced concrete structures affected by reinforcement corrosion, the use of electrochemical techniques for the determination of relevant parameters in this regard becomes a major area of study. 
Therefore the electrochemical techniques are widely used for the study of rebar corrosion in laboratories together with their application to real life structures [3].

The bond between steel and concrete is the mechanism which allows for effective force transfer. The load applied to the concrete member is transferred to the reinforcing steel through bond [4]. Bond of deformed bars is developed mainly by the bearing pressure of the bar ribs against the concrete [5]. One of the most important prerequisites of reinforced concrete construction is adequate bond between the reinforcement and the concrete. Hence present study aims to investigate the effect of corrosion on performance of Reinforced concrete beams, in particular on the bond strength and load carrying characteristics and deflection characteristics and maximum crack width. Following are the main highlights of the study:

1. Accelerated corrosion using impressed current technique was adopted for achieving the desired corrosion levels.

2. NBS RC beams have been cast and tested for bond strength by two-point loading flexural strength.

3. OPC and PPC concrete were used for preparing the beam specimens.

\section{Experimental}

Details of experiments, materials used, and method of testing are explained below.

\section{Materials}

Materials used for the experimental investigation are tested as per code provisions:

Cement - Ordinary portland cement and Portland pozzolona cement were used. Cements used for the study are tested as per IS: 8112-1989 [6] for OPC and IS 1489 (Part-1):1991 [7] for PPC recommendations. Setting time, specific gravity and compressive strength of results are tabulated in Table 1 and Table 2 respectively.

Table 1. Test results on Characteristics of OPC

\begin{tabular}{clcc}
\hline SI No & \multicolumn{1}{c}{ Test Parameters } & Results & $\begin{array}{c}\text { As per IS 8112:1989 } \\
\text { (Specifications of 43 Grade OPC) }\end{array}$ \\
\hline 1 & $\begin{array}{l}\text { Initial setting and } \\
\text { final setting time }\end{array}$ & $75 \mathrm{~min}$ and $260 \mathrm{~min}$ & $\begin{array}{c}\text { Not less than } 30 \mathrm{~min} . \\
\text { and not more than } 600 \mathrm{~min}\end{array}$ \\
\hline 2 & Specific gravity & 3.1 & \\
\hline 3 & Compressive strength: & & \\
& 3 Days & $24.09 \mathrm{~N} / \mathrm{mm}^{2}$ & Not less than $23 \mathrm{~N} / \mathrm{mm}^{2}$ \\
& 7 Days & $34.48 \mathrm{~N} / \mathrm{mm}^{2}$ & Not less than $33 \mathrm{~N} / \mathrm{mm}^{2}$ \\
& 28 Days & $46.85 \mathrm{~N} / \mathrm{mm}^{2}$ & Not less than $43 \mathrm{~N} / \mathrm{mm}^{2}$ \\
\hline
\end{tabular}

Fine Aggregate - Physical tests on fine aggregates were conducted as per IS 383-1970 [8] and specific gravity, water absorption and moisture content and grading results are presented in Table 3.

Coarse Aggregate - Size of aggregate used was $20 \mathrm{~mm}$ downsize and $12.5 \mathrm{~mm}$ down size angular type coarse aggregate. Physical tests on aggregates were conducted as per IS 383-1970 [8]. Specific gravity, water absorption and moisture content results are tabulated in Table 4. 
Table 2. Test results on Characteristics of $P P C$

\begin{tabular}{clcc}
\hline SI No & \multicolumn{1}{c}{ Test parameters } & Results & $\begin{array}{c}\text { As per IS 1489 (Part-I): 1991 (Specifications } \\
\text { of Portland Pozzolana cement) }\end{array}$ \\
\hline 1 & $\begin{array}{l}\text { Initial setting and } \\
\text { final setting time }\end{array}$ & 76 min and $270 \mathrm{~min}$ & $\begin{array}{c}\text { Not less than } 30 \mathrm{~min} . \\
\text { and not more than } 600 \mathrm{~min}\end{array}$ \\
\hline 2 & Specific gravity & 2.91 & \\
\hline 3 & Compressive strength: & & \\
& 3 Days & $16.64 \mathrm{~N} / \mathrm{mm}^{2}$ & Not less than $16 \mathrm{~N} / \mathrm{mm}^{2}$ \\
& 7 Days & $26.54 \mathrm{~N} / \mathrm{mm}^{2}$ & Not less than $22 \mathrm{~N} / \mathrm{mm}^{2}$ \\
& 28 Days & $39.84 \mathrm{~N} / \mathrm{mm}^{2}$ & Not less than $33 \mathrm{~N} / \mathrm{mm}^{2}$ \\
\hline
\end{tabular}

Table 3. Test result of fine aggregate used for concrete mix

\begin{tabular}{clc}
\hline SI No & Test Parameters & Results \\
\hline 1 & Specific gravity & 2.6 \\
\hline 2 & Water absorption & $2.0 \%$ \\
\hline 3 & Moisture content & $5.0 \%$ \\
\hline 4 & Grading & Zone I \\
\hline
\end{tabular}

Table 4. Test result of $20 \mathrm{~mm}$ down size used for concrete mix

\begin{tabular}{clc}
\hline SI No & Test Parameters & Results \\
\hline 1 & Specific gravity & 2.8 \\
\hline 2 & Water absorption & $0.5 \%$ \\
\hline 3 & Moisture content & Nil \\
\hline 4 & Shape & Angular \\
\hline
\end{tabular}

Reinforcing steel - Tensile strength of reinforcing steel bar was tested using Universal Testing Machine (UTM). Stress-strain curves for $25 \mathrm{~mm}$ Thermo Mechanically Treated (TMT) Fe-415 reinforcing steel bar was obtained by plotting tension test data. Typical stress-strain curve for $25 \mathrm{~mm}$ bar is shown in Figure 1. The yield strength and ultimate strength are $485 \mathrm{~N} / \mathrm{mm}^{2}$ and $589 \mathrm{~N} / \mathrm{mm}^{2}$ respectively.

Mix design details

According to the codal recommendation of IS 456-2000 [9] minimum concrete grade to be adopted in coastal environment is $\mathrm{M} 30$ and maximum water cement ratio of 0.45 . Target strength of $30 \mathrm{~N} / \mathrm{mm}^{2}$ was considered for the study. To Control the proportion of water in freshly mixed concrete is to specify an upper limit for "slump". Hence a slump range of 50-60 mm was selected for the present study. Mix design calculations were made as per IS 10262-2009 [10]. Test results of materials were used in the calculation of determination of mix proportions. After several trials the mix proportion of 1:1.77:2.87 was achieved with an addition of $2 \mathrm{ml} / \mathrm{kg}$ of commercially available chemical admixture for both OPC and PPC concrete.

\section{Preparation of test specimens}

For the present study National Bureau of Standard (NBS) beam specimens of size $2.44 \times 0.457 \times 0.203 \mathrm{~m}$ (Figure 2) was used [11]. Before placing of concrete in beam molds, one 
blue color multi-strand copper wire of $4 \mathrm{~cm}^{2}$ cross sectional area was connected at one end of rebar, and soldered to reinforcement bar and also covered with $\mathrm{M}$-seal to prevent corrosion at that area. This wire is protruded to the surface level to induce electric current. Similar steps were followed at the other end and one black color, multi-strand copper wire of $2 \mathrm{~cm}^{2}$ cross sectional area was connected to reinforcement bar, which helps in the monitoring process of corrosion rate.

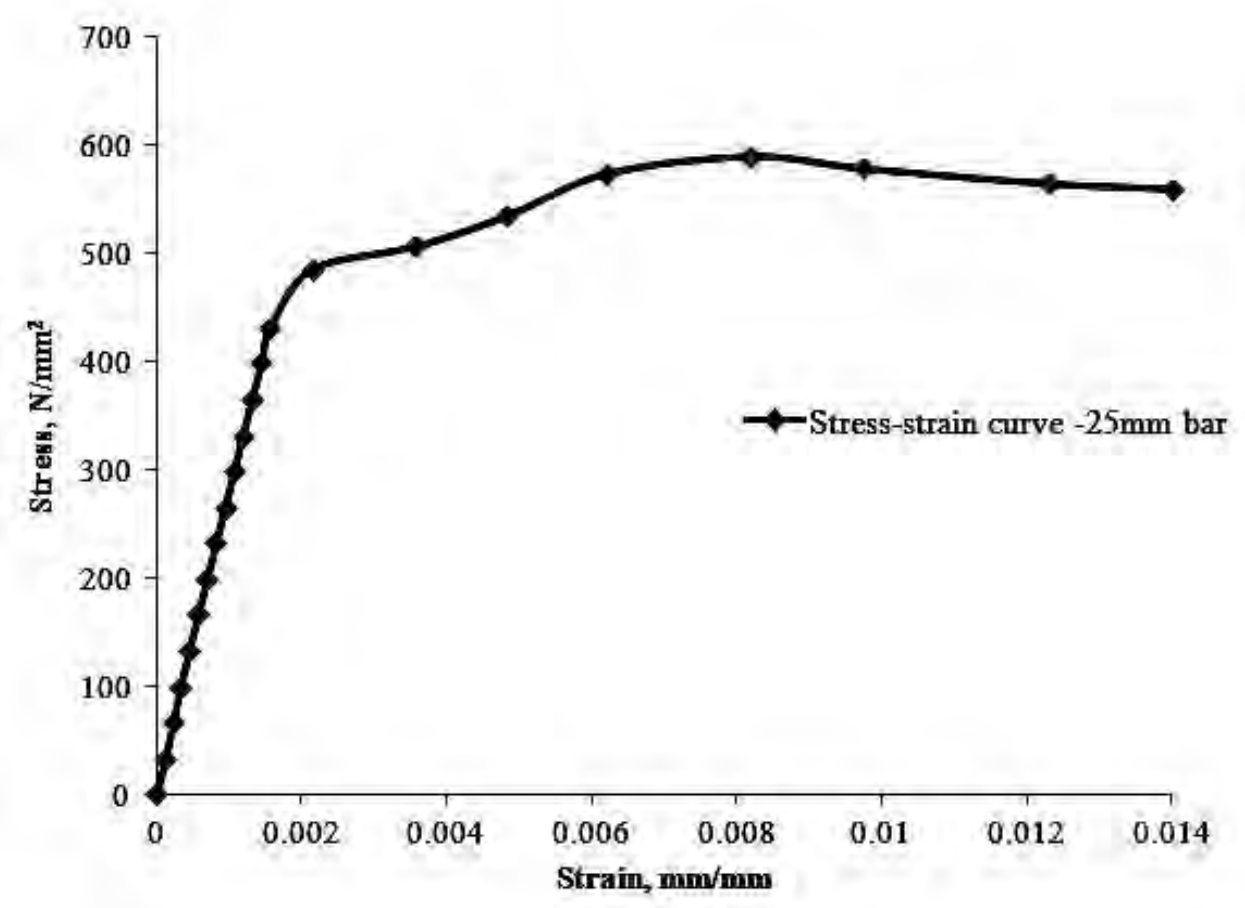

Figure 1. Stress-strain curve for $25 \mathrm{~mm}$ diameter TMT Fe-415 reinforcing steel bar
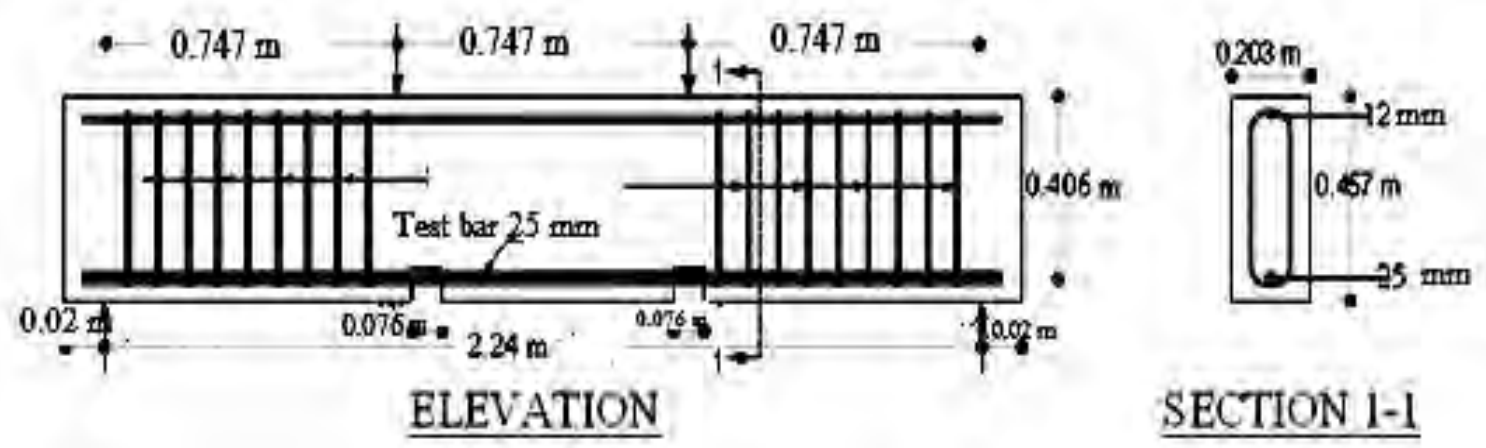

\section{SECTION 1-1}
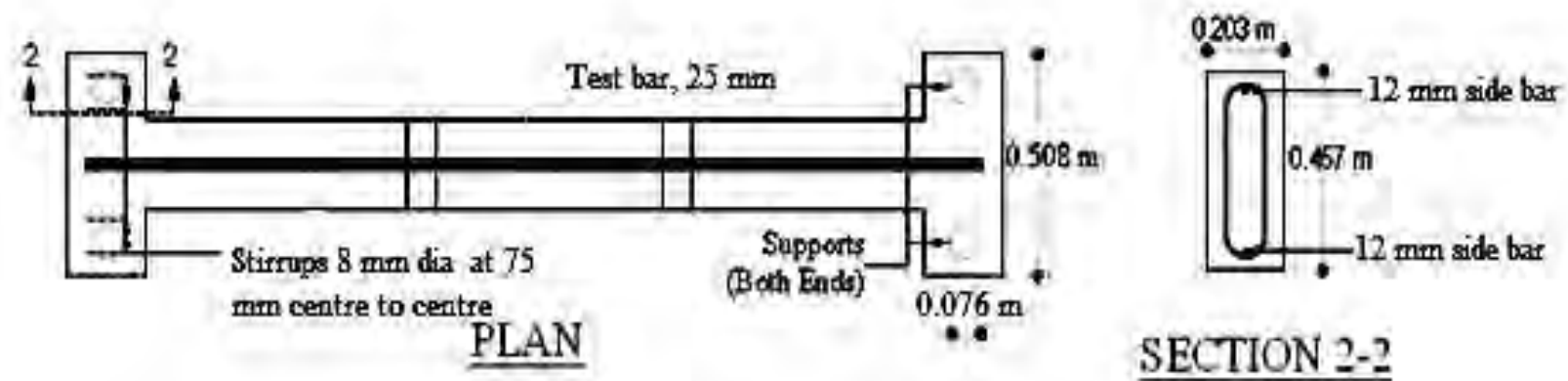

SECTION 2-2

Figure 2. Reinforcement details of NBS beam specimen [11] 


\section{Accelerated corrosion technique}

Under natural conditions the process of reinforcement corrosion is very slow; so laboratory studies need an acceleration of corrosion process to achieve a short test period. This can be accomplished by applying a constant potential or an electric current of constant magnitude to the embedded steel [12]. Hence accelerated corrosion technique was used in the present study to achieve different degree of corrosion levels.

After curing of beam specimens for 28 days, specimens were lifted and shifted to the corrosion tank to induce desired corrosion levels. Electrochemical corrosion technique was used to accelerate the corrosion of steel bars embedded in beam specimens. Specimens were partially immersed in a $5 \% \mathrm{NaCl}$ solution for duration of 8 days; direction of current was arranged such that, rebars embedded inside the concrete specimens served as anode. Steel plate which was placed along the length of beam functions as cathode. Current required achieving different corrosion levels can be obtained using Faraday's law (Eq. 3) [13]. Based on the calculation amount of 2.5 to $10 \mathrm{~A}$ current at the variation of $2.5 \mathrm{~A}$ was applied to obtain the required corrosion level i.e. 2.5 to $10 \%$ at the variation of $2.5 \%$ respectively. For each trial, three specimens were considered. A Schematic representation of corrosion test set-up used for accelerated corrosion process is shown in Figure 3.

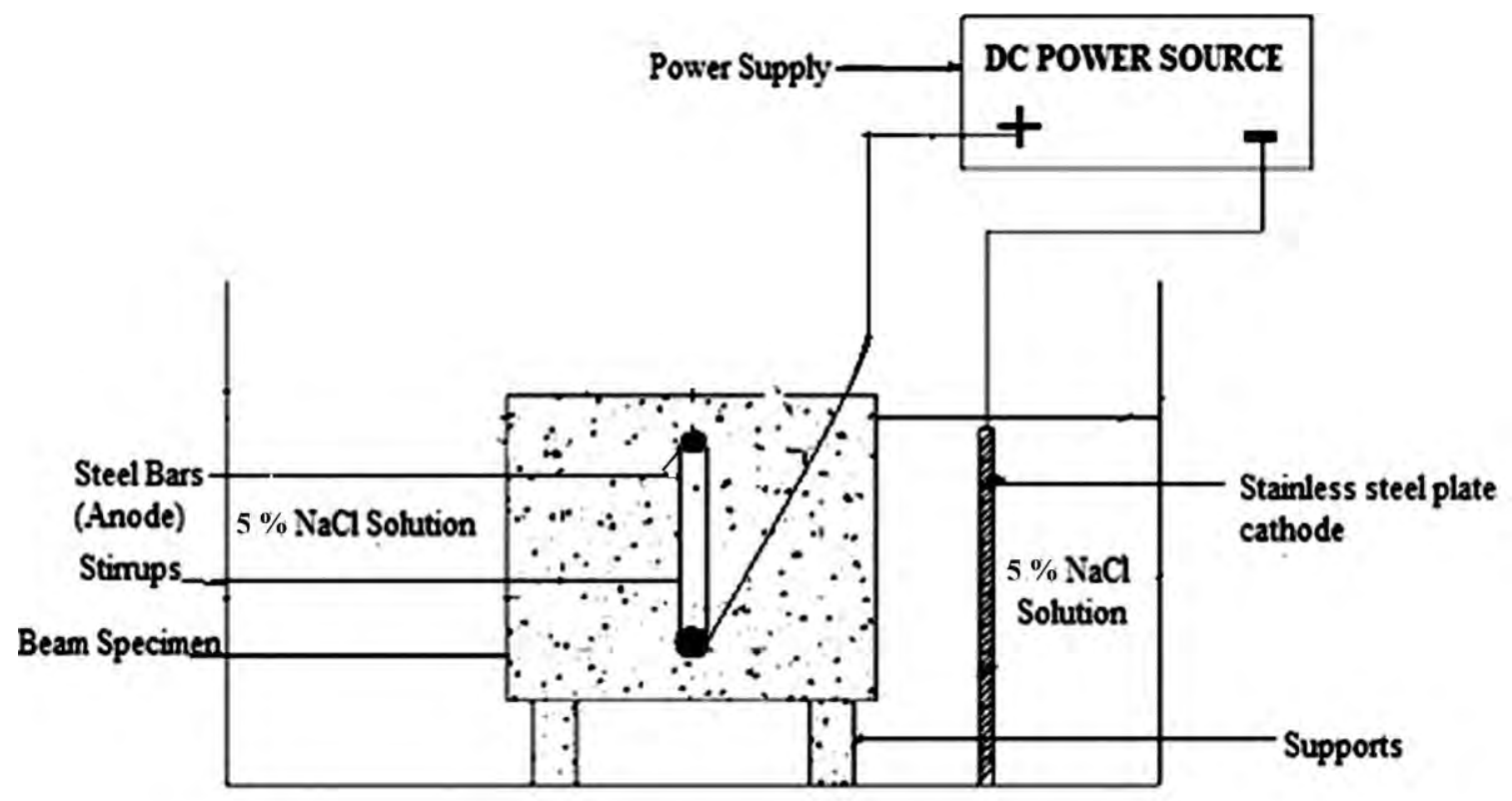

Figure 3. Schematic representation of accelerated corrosion of beam specimen

Calculation of amount of current required to obtain different corrosion levels

From Faraday's law,

$$
\begin{aligned}
& i_{\text {corr }}=\frac{\left(w_{\mathrm{i}}-w_{\mathrm{f}}\right) F}{\pi D L W T} \\
& \rho=\frac{\left(w_{\mathrm{i}}-w_{\mathrm{f}}\right)}{w_{\mathrm{i}}} 100
\end{aligned}
$$

Eq (2) in Eq. (1)

$$
i_{\text {app }}=i_{\text {corr }}=\frac{\rho W_{\mathrm{i}} F}{100 \pi D L W T}
$$


where $i_{\text {corr }}=$ corrosion current density; $i_{\text {app }}=$ applied current; $\rho=$ degree of corrosion $W_{i}=$ Initial weight of steel $(20,000 \mathrm{~g}) ; F=96487 \mathrm{As} ; D=$ bar diameter; $L=$ length of bar; $W=$ equivalent weight of steel $(27.925 \mathrm{~g}) ; T=$ time in seconds.

\section{Corrosion rate measurements}

After completion of accelerated corrosion, corrosion rate was measured with Applied Corrosion Monitoring (ACM) instrument (Figure 4) based on linear polarization resistance (LPR) method to assure the achieved desired degree of corrosion levels in beam specimens after inducing corrosion for a particular duration.

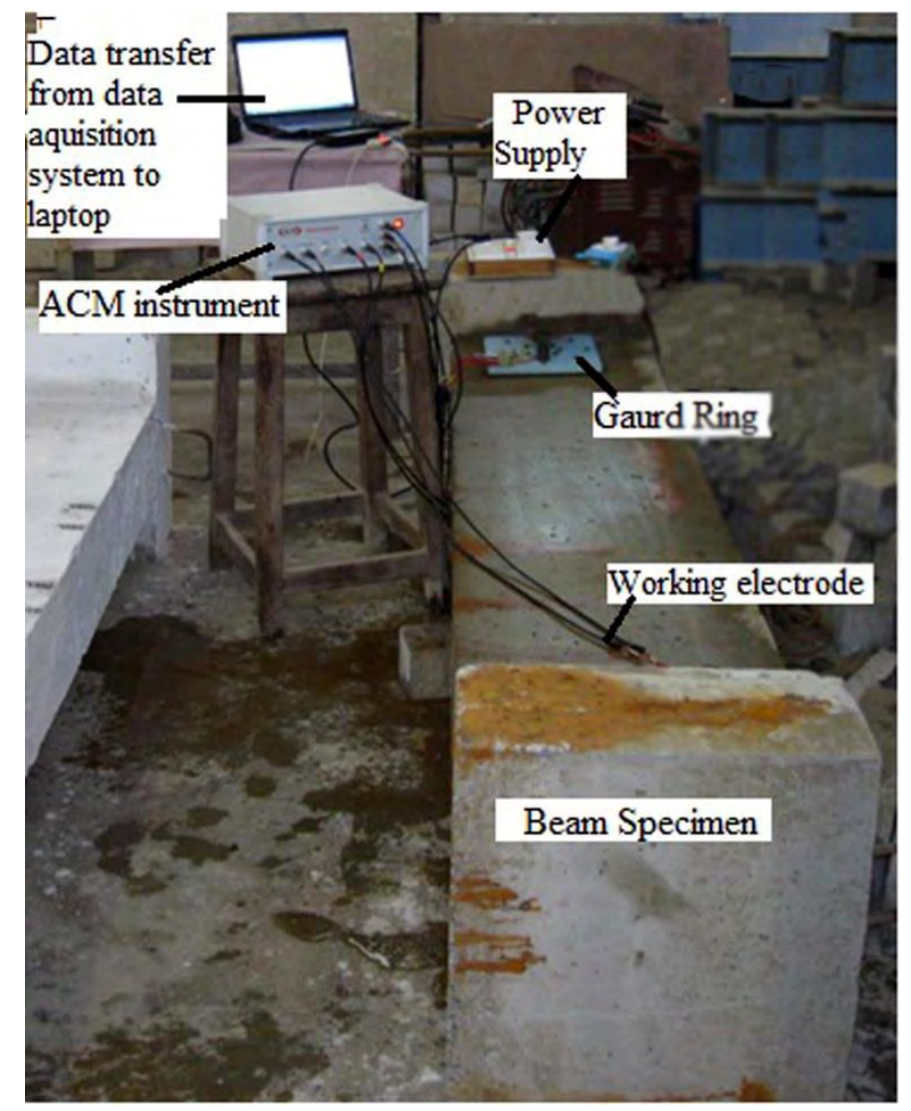

Figure 4. Corrosion monitoring set up

Corrosion current density was calculated by using the Stern-Geary formula [14].

$$
i_{\text {corr }}=\frac{B}{R_{\mathrm{p}}}
$$

where, $i_{\text {corr }}=$ corrosion current density, $\mu \mathrm{A} / \mathrm{cm}^{2} ; R_{\mathrm{p}}=$ polarization resistance, $\mathrm{k} \Omega \mathrm{cm}^{2} ; B=26 \mathrm{mV}$ (for steel in active condition this value is normally used) [15].

\section{Test setup used for flexural bond study}

Test set up used for the present study is shown in Figure $5 \mathrm{a}$. Beam specimens were tested under two point loading condition. The load was applied at $15 \mathrm{kN}$ increments. Proving ring of 50 tonne capacity was used to note the applied load.

Strain value recordings have been done by using demec gauges at every load interval. Positions of demec targets have been shown in Figure 5b. Maximum crack width was measured using Crack microscope (Figure 6). Deflection recordings were done by using dial gauges. Dial gauges were indicated in Figure 7. 


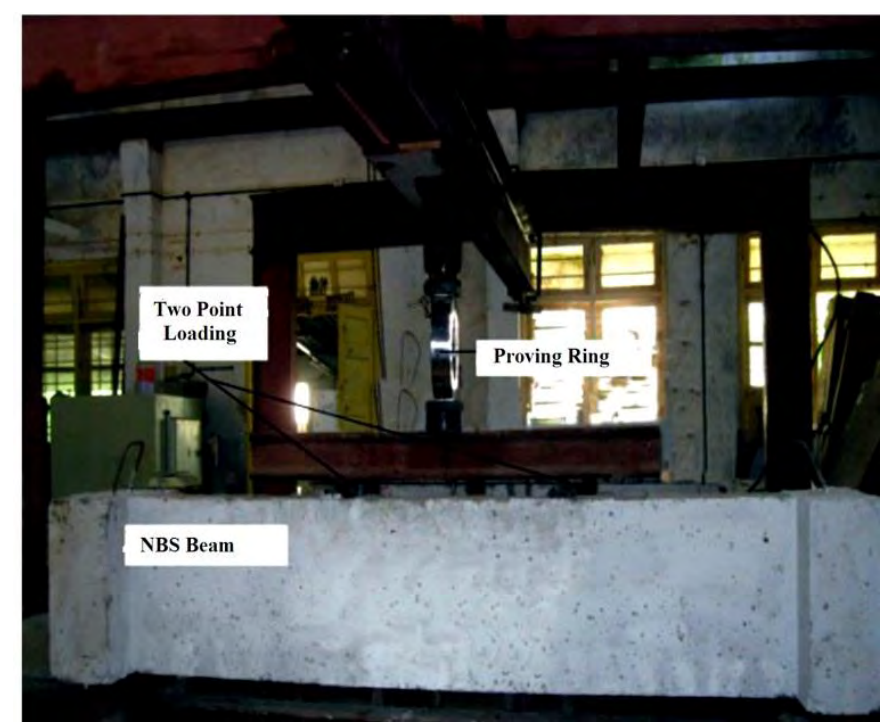

Figure 5(a). Test set up of NBS beam Specimen

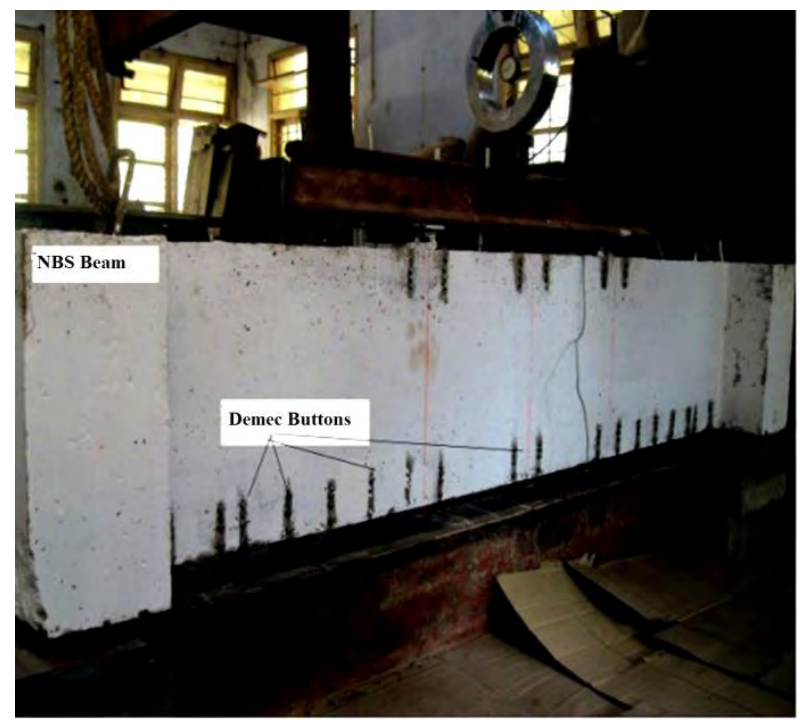

Figure 5(b). Demec buttons were at $100 \mathrm{~mm} \mathrm{c/c}$

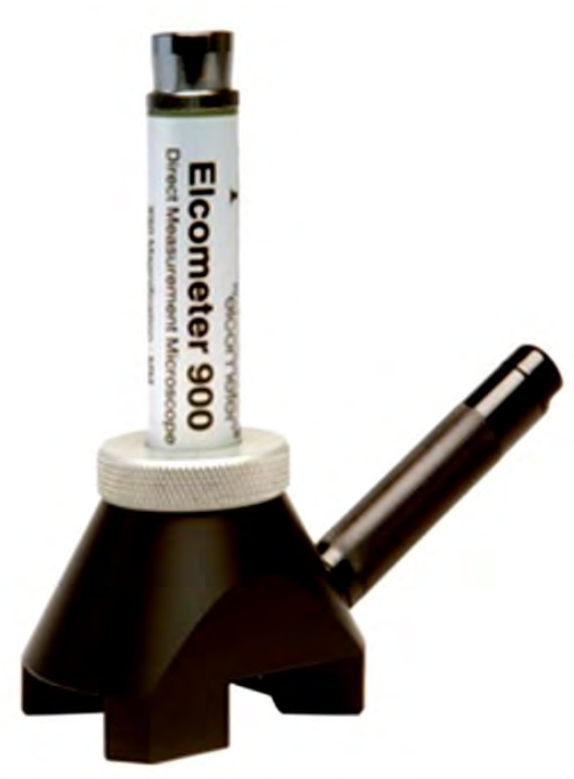

Figure 6. Concrete crack microscope

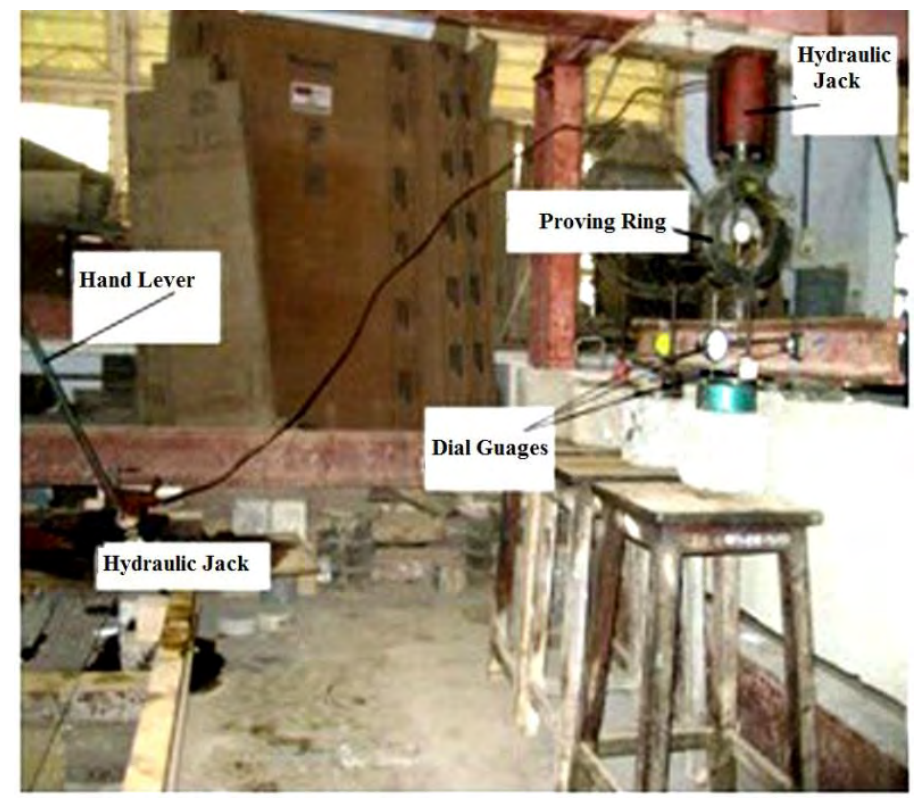

Figure 7. Positions of dial gauges

\section{Determination of bond stress}

Average bond stress values were obtained from Eq. (6).

$$
\tau_{\mathrm{bd}}=\frac{\varphi_{1} f_{\mathrm{s}}}{4 l_{\mathrm{d}}}
$$

where, diameter of bar

$$
\varphi_{1}=\varphi \sqrt{1-\frac{p}{100}}
$$

$\tau_{\mathrm{bd}}=$ Average bond stress, $\mathrm{N} / \mathrm{mm}^{2}$

$\phi=$ initial diameter $25 \mathrm{~mm}$

$\phi_{1}=$ Reduced diameter values are presented in Table 5. 
$p=$ Weight loss in percentage

$I_{\mathrm{d}}=$ Embedment length of the bar $(747 \mathrm{~mm})$ from the test setup

$f_{s}=$ Steel stress values have been obtained for initial and final strain values (slip region) of different corrosion levels from stress corresponding to strains at that load level.

Table 5. Reduced bar diameter for different levels of corrosion

\begin{tabular}{cc}
\hline Corrosion level, $\%$ & Bar diameter, $\mathbf{~ m m}$ \\
\hline 0 & 25.00 \\
\hline 2.5 & 24.69 \\
\hline 5 & 24.37 \\
\hline 7.5 & 24.04 \\
\hline 10 & 23.72 \\
\hline
\end{tabular}

\section{Results and Discussion}

Compressive strength of control cube after 28 days of curing was $35 \mathrm{~N} / \mathrm{mm}^{2}$ and $33 \mathrm{~N} / \mathrm{mm}^{2}$ for $\mathrm{OPC}$ and PPC concrete respectively.

\section{Measurement of corrosion current density}

Corrosion rate is measured in terms of corrosion current density, $i_{\text {corr }}$, and is a quantitative index, which represents an overall estimate of the corrosion attack on reinforcement.

Corrosion current density values were calculated for each specimen from ACM instrument for different grids and average value was considered for different corrosion levels to calculate the weight loss, \%. Obtained corrosion levels or weight loss for applied current are shown in Figure 8. It is seen that corrosion levels increases linearly with the increase in the applied current. From Figure 8 corrosion levels for the applied current, $A$, can be calculated as:

$$
\begin{array}{lll}
y=0.96 x-0.22 & R^{2}=0.995 & \text { (PPC Concrete) } \\
y=0.98 x-0.54 & R^{2}=0.998 & \text { (OPC Concrete) }
\end{array}
$$

where; $x=$ applied current, $A$ and $y=$ obtained corrosion level, $\%$.

\section{Experimental Investigation on ultimate load carrying capacity and bond stress of RC member}

In the present study, 3 control specimens and 12 corroded specimens ( 3 sets each for $2.5 \%$, to $10 \%$ at $2.5 \%$ variation of corrosion) were considered for OPC and PPC concrete beam specimens.

Ultimate load carrying capacity, deflection and crack propagation of NBS beams

Effect of corrosion on ultimate load carrying capacity is shown in Figure 9. As the degree of corrosion level increases load carrying capacity decreases (Figure 9). It is also observed that for every percentage increase in corrosion level there is about $1.6 \%$ decrease in load carrying capacity.

From Figure 10 it is noticed that as the corrosion level increases deflection value increases. This is due to as the corrosion level increases cross sectional area reduces and leads to reduction in stiffness of reinforcement.

From Figure 11 it is observed that at low corrosion levels ( 0 to 5\%) crack width is less but as the corrosion level increases ( $7.5 \%$ to $10 \%$ ) crack width increases rapidly. From Figure 12 it is seen that as the load level increases strain value increases linearly in the initial stage. 


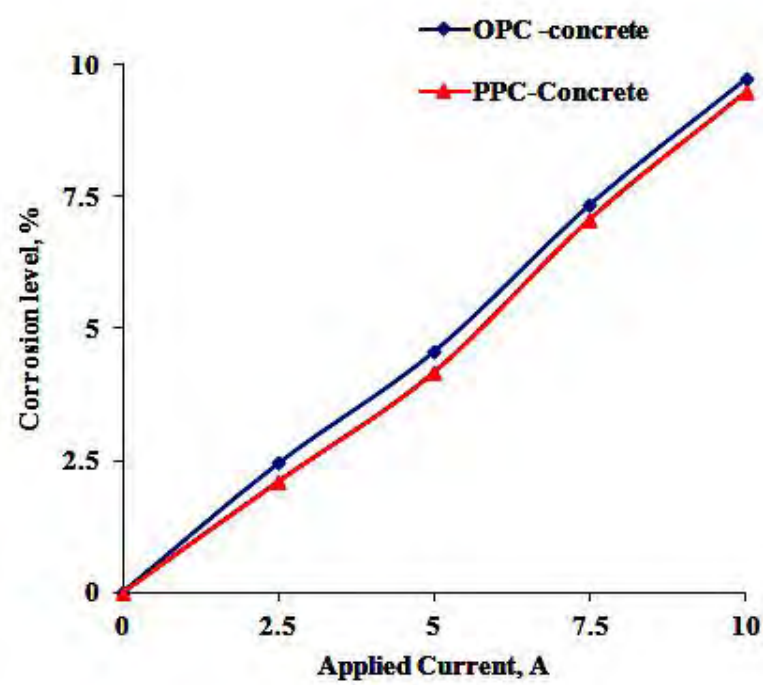

Figure 8. Variation of corrosion levels with Applied current

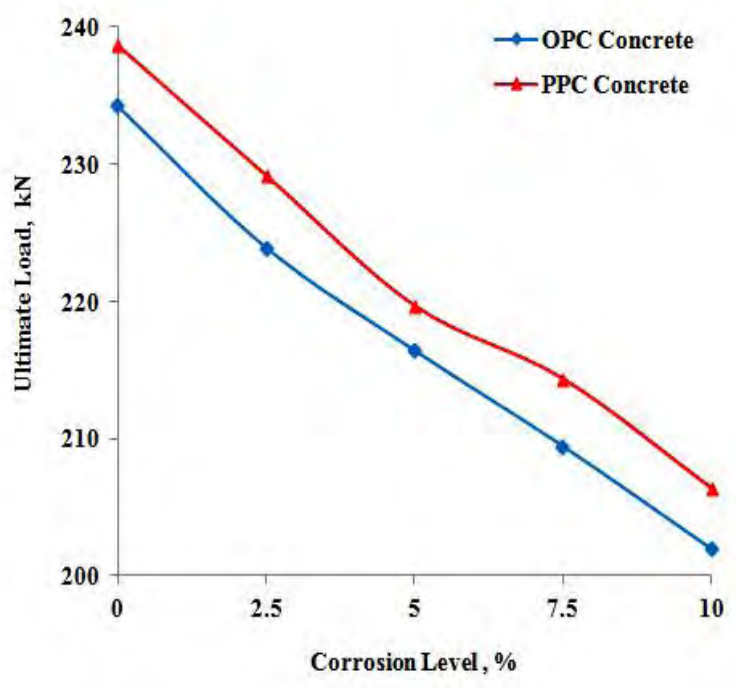

Figure 9. Effect of corrosion on ultimate load carrying capacity

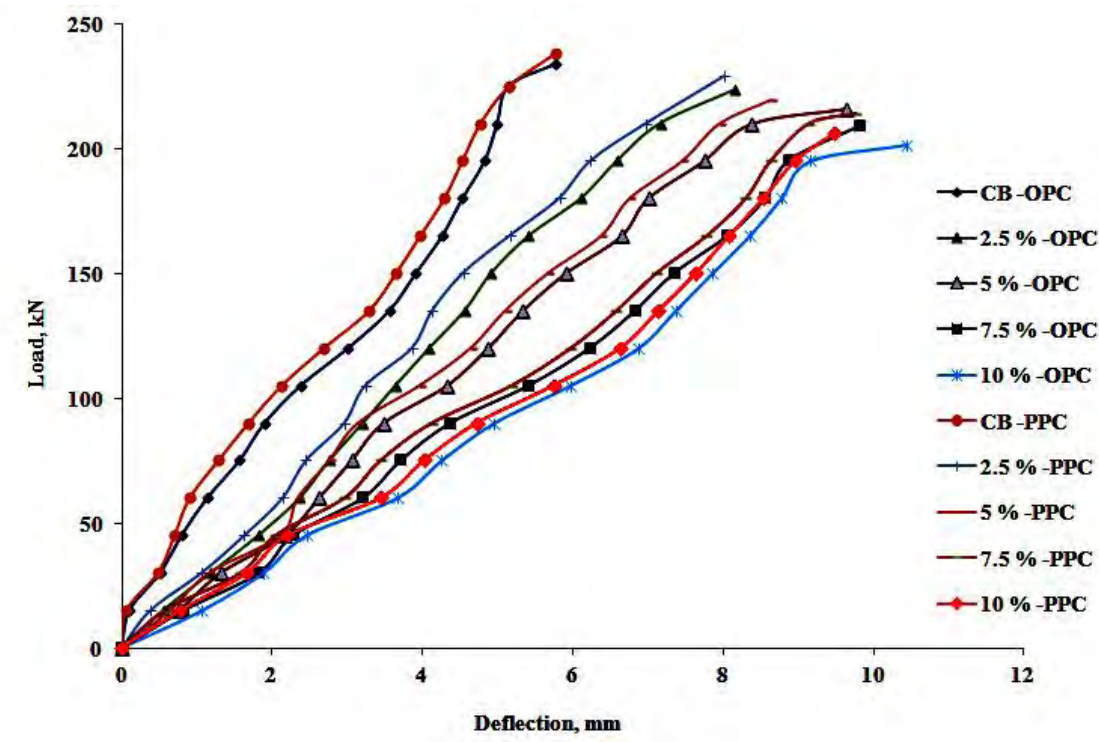

Figure 10. Effect of corrosion levels on central deflection of NBS beam

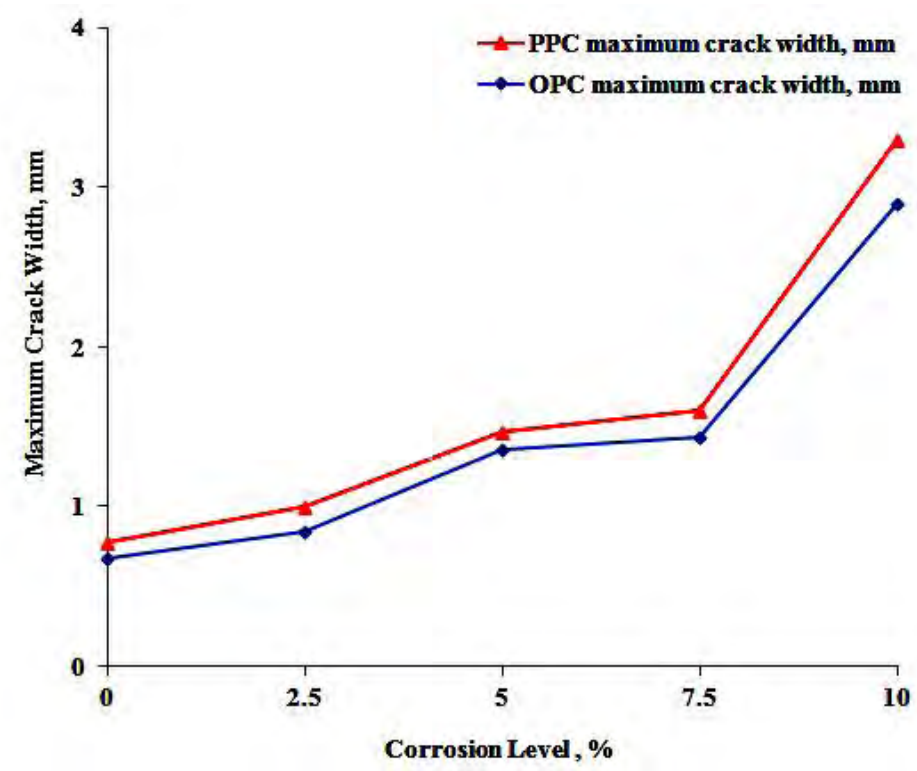

Figure 11. Effect of corrosion levels on maximum crack width of NBS beam 
Then at higher corrosion levels, rate of increase of strain is higher for the same increment of load level compared to lower levels of corrosion. Control beam specimen performs better at increased corrosion levels. It is also observed that there is a sudden increase in strain values observed for the applied load interval, in all beam specimens (Figures 12 to 15). Bond characteristic is dependent on characteristics of steel at interface and not in the body of reinforcement. From the stress strain curves it is clear that the sudden increase in strain levels without increase in stress is indicative of slip (sudden increases in strain value is much lesser than the yield strength of $25 \mathrm{~mm}$ diameter) characteristics owing to drop in bond. Higher the accelerated corrosion at surface lower is the stress level at which such slip occurs.

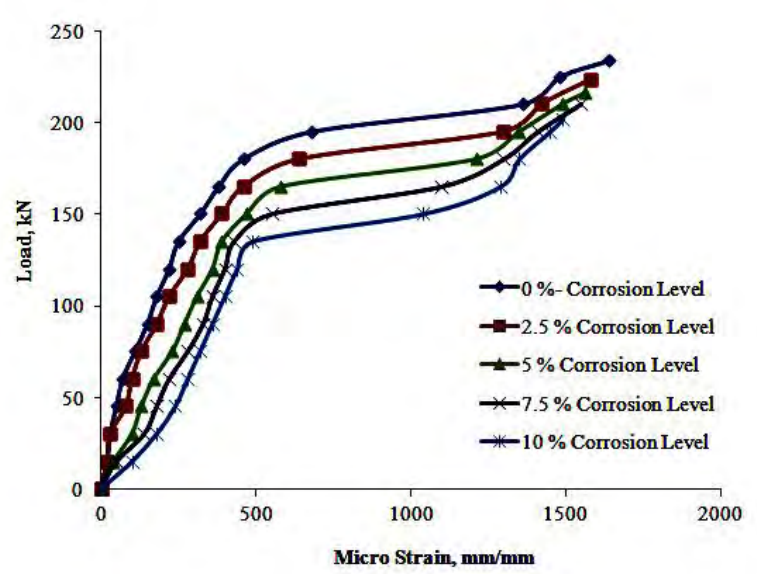

Figure 12. Effect of different levels of corrosion on stress strain behavior of OPC Concrete Beam specimens at left side loading Point (L); where, TRL-

Tension side Reinforcement level

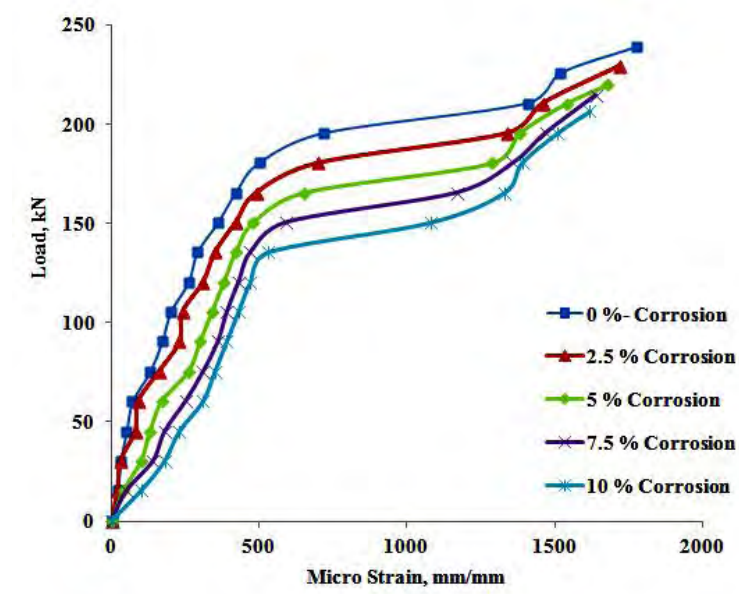

Figure 14. Effect of different levels of corrosion on stress strain behavior of PPC Concrete Beam specimens at right side loading Point (R); where, TRL-Tension side Reinforcement level

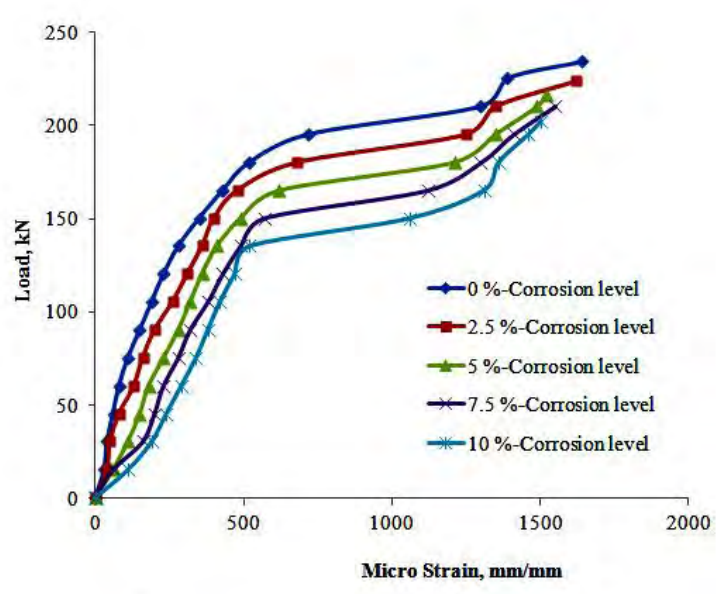

Figure 13. Effect of different levels of corrosion on stress strain behavior of OPC Concrete Beam specimens at right side loading Point (R); where,

TRL-Tension side Reinforcement level

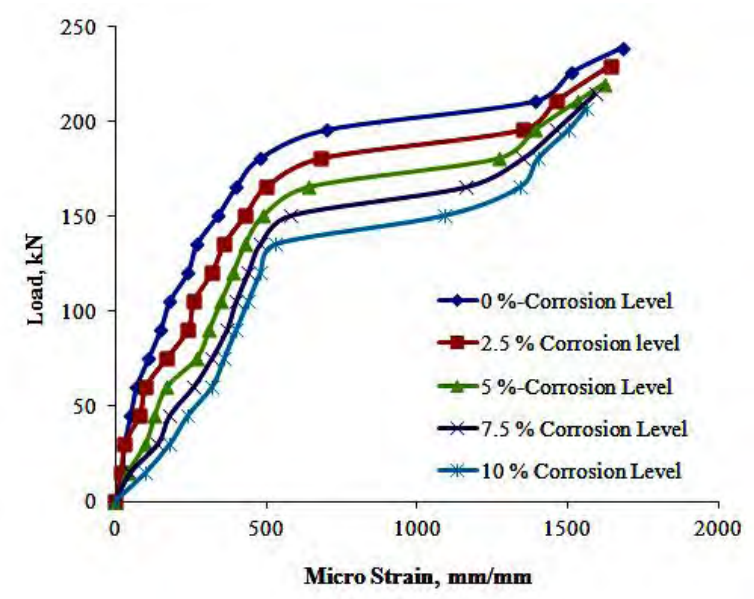

Figure 15. Effect of different levels of corrosion on stress strain behavior of PPC Concrete Beam specimens at left side loading Point (L); where, TRL-Tension side Reinforcement level

Bar stress and bond stress performance of NBS beam

From Table 6 and Table 7 it is observed that as the corrosion level increases bond stress value decreases. Percentage reduction in bond stress for different levels of corrosion i.e. $2.5 \%, 5 \%$, $7.5 \%$ and $10 \%$ with respect to control specimen were $6.59 \%, 13.17 \%, 21.56 \%$ and $29.34 \%$ respectively for OPC concrete beam specimens and for PPC concrete beam specimens $4.32 \%$, $10.65 \%, 18.93 \%$ and $26.04 \%$ respectively. 
From Figure 16 and Figure 17 it is exhibited that bond stress approximately drops for about $2.6 \%$ and $2.1 \%$ for (initial strain value) OPC and PPC concrete beam specimen and also $2 \%$ and $2.1 \%$ (final strain value) for OPC and PPC concrete beam specimens respectively for every percentage increase in corrosion level.

Table 6. Bar force, reduced diameter and bond stress performance for different degree of corrosion in NBS beam

\begin{tabular}{|c|c|c|c|c|c|c|c|c|}
\hline & \multicolumn{6}{|c|}{ Bar force and Bond Stress values at slip region in strain values } \\
\cline { 2 - 9 } & \multicolumn{4}{|c|}{ Initial strain values } \\
\hline $\begin{array}{c}\text { Corrosion } \\
\text { level, \% }\end{array}$ & $\begin{array}{c}\text { Micro } \\
\text { Strain }\end{array}$ & $\begin{array}{c}\text { Stress in } \\
\text { bar, } \\
\mathrm{N} / \mathrm{mm}^{2}\end{array}$ & $\begin{array}{c}\text { Reduced } \\
\text { Diameter, } \\
\mathrm{mm}\end{array}$ & $\begin{array}{c}\text { Bond } \\
\text { Stress, } \\
\mathrm{N} / \mathrm{mm}^{2}\end{array}$ & $\begin{array}{c}\text { Micro } \\
\text { Strain }\end{array}$ & $\begin{array}{c}\text { Stress in } \\
\text { bar, } \\
\mathrm{N} / \mathrm{mm}^{2}\end{array}$ & $\begin{array}{c}\text { Reduced } \\
\text { Diameter, } \\
\mathrm{mm}\end{array}$ & $\begin{array}{c}\text { Bond } \\
\text { Stress, } \\
\mathrm{N} / \mathrm{mm}^{2}\end{array}$ \\
\hline 0 & 700 & 199.21 & 25.00 & 1.67 & 1330 & 367.96 & 25.00 & 3.08 \\
\hline 2.5 & 660 & 188.85 & 24.69 & 1.56 & 1275 & 353.58 & 24.69 & 2.92 \\
\hline 5 & 600 & 177.59 & 24.37 & 1.45 & 1210 & 337.08 & 24.37 & 2.75 \\
\hline 7.5 & 560 & 163.25 & 24.04 & 1.31 & 1110 & 310.00 & 24.04 & 2.49 \\
\hline 10 & 505 & 148.13 & 23.72 & 1.18 & 1050 & 293.93 & 23.72 & 2.33 \\
\hline
\end{tabular}

Table 7. Bar force, reduced diameter and bond stress performance for different levels of corrosion in PPC concrete beam specimens

\begin{tabular}{|c|c|c|c|c|c|c|c|c|}
\hline & \multicolumn{4}{|c|}{ Bar force and Bond Stress values at slip region (PPC concrete beam specimens) } \\
\cline { 2 - 9 } & \multicolumn{4}{|c|}{ Initial strain values } \\
\hline $\begin{array}{c}\text { Corrosion } \\
\text { level, \% }\end{array}$ & $\begin{array}{c}\text { Micro } \\
\text { Strain }\end{array}$ & $\begin{array}{c}\text { Stress in } \\
\text { bar, } \\
\mathrm{N} / \mathrm{mm}^{2}\end{array}$ & $\begin{array}{c}\text { Reduced } \\
\text { Diameter, } \\
\mathrm{mm}\end{array}$ & $\begin{array}{c}\text { Bond } \\
\text { Stress, } \\
\mathrm{N} / \mathrm{mm}^{2}\end{array}$ & $\begin{array}{c}\text { Micro } \\
\text { Strain }\end{array}$ & $\begin{array}{c}\text { Stress in } \\
\text { bar, } \\
\mathrm{N} / \mathrm{mm}^{2}\end{array}$ & $\begin{array}{c}\text { Reduced } \\
\text { Diameter, } \\
\mathrm{mm}\end{array}$ & $\begin{array}{c}\text { Bond } \\
\text { Stress, } \\
\mathrm{N} / \mathrm{mm}^{2}\end{array}$ \\
\hline 0 & 710 & 201.75 & 25.00 & 1.69 & 1400 & 387.00 & 25.00 & 3.24 \\
\hline 2.5 & 690 & 196.46 & 24.69 & 1.62 & 1345 & 371.88 & 24.69 & 3.07 \\
\hline 5 & 645 & 185.04 & 24.37 & 1.51 & 1280 & 354.85 & 24.37 & 2.89 \\
\hline 7.5 & 585 & 170.13 & 24.04 & 1.37 & 1165 & 325.13 & 24.04 & 2.62 \\
\hline 10 & 530 & 154.94 & 23.72 & 1.23 & 1085 & 303.13 & 23.72 & 2.41 \\
\hline
\end{tabular}

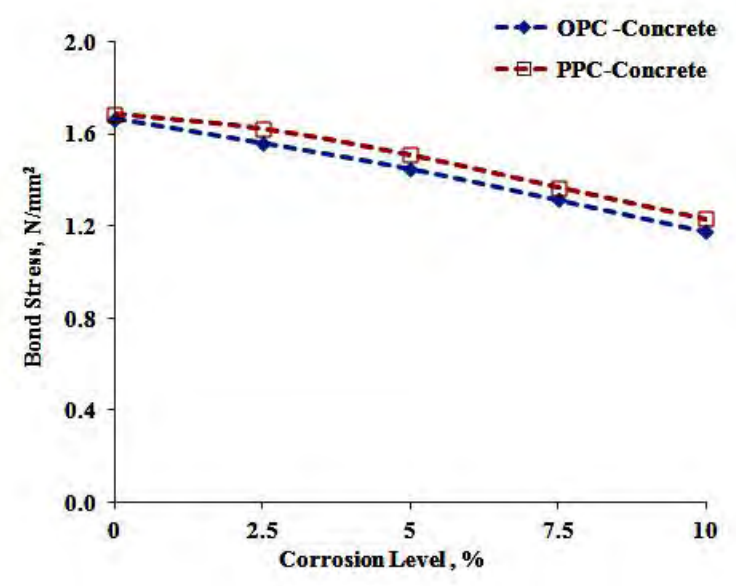

Figure 16. Effect of corrosion levels on bond stress of slip region at final strain values

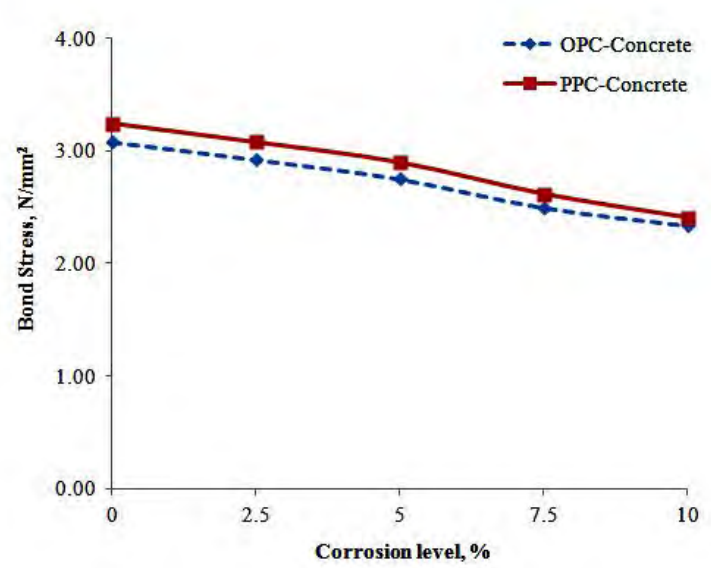

Figure 17. Effect of corrosion levels on bond stress of slip region at final strain values

Bond stress values for different degree of corrosion can be calculated from following equations obtained from Figure 16 and Figure 17, where $x=$ corrosion levels, $\%$ and $y=$ bond stress, N/mm ${ }^{2}$. At initial slip point 
$\begin{array}{lll}\text { (OPC concrete) } & y=-0.049 x+1.678 & R^{2}=0.996 \\ \text { (PPC concrete) } & y=-0.046 x+1.718 & R^{2}=0.982\end{array}$

At end slip point

$\begin{array}{lll}\text { (OPC concrete) } & y=-0.076 x+3.099 & R^{2}=0.992 \\ \text { (PPC concrete) } & y=-0.084 x+3.269 & R^{2}=0.990\end{array}$

\section{Conclusions}

Based on the detailed experimental investigations, following conclusions are drawn:

Reinforcement corrosion leads to the decline of load carrying capacity of NBS RC beam specimens. For every percentage increase in corrosion level, there is about $1.6 \%$ decrease in load carrying capacity. For increasing corrosion level, strain values increase in the initial stages. Then at higher corrosion levels rate of increase of strain is higher for the same increment of load level, compared to the lower levels of corrosion. Crack width is less at the lower level of corrosion ( 0 to $5 \%$ ), after that it increases rapidly ( 7.5 to $10 \%$ ).

Reinforcement corrosion causes degradation of bond behavior. The strain value becomes large due to corrosion and the larger the corrosion lesser the bond stress value. Proposed regression equation is very much useful for quick assessment to predict the bond strength values for different corrosion levels in structure. Though the state of the art states about blended cements the research results done by OPC concrete is very much useful for the already existing structures subjected to corrosion.

\section{References}

[1] S. Bhaskar, B. H. Bharatkumar, G. Ravindra, M. Neelamegam, Journal of Structural Engineering (CSIR-SERC), 37 (2010) 37-42.

[2] T. Maheswaran, J. G. Sajavan, Journal of Material Concrete Research, 56 (2004) 359-366.

[3] C. Andrade, C. Alonso, Journal of Construction Building Materials, 10 (1996) 315-328.

[4] R. Park, T. Paulay, Reinforced Concrete Structures, John Wiley \& Sons, Inc. New York (1975).

[5] L. A. Lutz, P. Gergely, ACI Materials Journal, 11 (1967) 711-721.

[6] IS 8112: 43 Grade Ordinary Portland cement - Specification Bureau of Indian Standards (1989).

[7] IS 4031: Methods of physical tests for hydraulic cement, Bureau of Indian Standards (1988).

[8] IS 383: Indian Standard Specification for Coarse and Fine aggregates from natural sources for Concrete (1970).

[9] IS 456: Indian standards Code of Practice for Plain and Reinforced Concrete (2000).

[10] IS 10262: Recommended guidelines for concrete mix design, Bureau of Indian Standards (2009).

[11] R. J. Paul, Master Thesis, Department of Civil Engineering and Applied Mechanics, Mc Gill University Canada (1978) p. 66.

[12] S. Care, A. Raharinaivo, Cement and Concrete Research, 37 (2007) 1598-1612.

[13] S. Ahamad, The Arabian Journal of Science and Engineering, 34 (2009) 95-104.

[14] B. Pradhan, B. Bhattacharjee, Construction and Building Materials, 23 (2009) 2346- 2356.

[15] M. G. Fontana, Corrosion Engineering, Tata McGraw-Hill Education (2005).

(C) 2014 by the authors; licensee IAPC, Zagreb, Croatia. This article is an open-access article distributed under the terms and conditions of the Creative Commons Attribution license (http://creativecommons.org/licenses/by/3.0/) (cc) Br 